\title{
Advances in NANI and NAPI accounting for the Baltic drainage basin: spatial and temporal trends and relationships to watershed TN and TP fluxes
}

\author{
Bongghi Hong • Dennis P. Swaney (D) Michelle McCrackin • Annika Svanbäck • \\ Christoph Humborg • Bo Gustafsson - Alexandra Yershova - Aliaksandr Pakhomau
}

Received: 7 October 2016/ Accepted: 1 April 2017/Published online: 9 April 2017

(C) The Author(s) 2017. This article is an open access publication

\begin{abstract}
In order to assess the progress toward eutrophication management goals, it is important to understand trends in land-based nutrient use. Here we present net anthropogenic nitrogen and phosphorus inputs (NANI and NAPI, respectively) for 2000 and 2010 for the Baltic Sea watershed. Overall, across the entire Baltic, between the 5-year periods centered on 2000 and 2010, NANI and NAPI decreased modestly by -6 and $-4 \%$, respectively, but with substantial regional variation, including major increases in the Gulf of Riga drainage basin ( +19 and $+58 \%$, respectively) and decreases in the Danish Straits
\end{abstract}

Responsible Editor: Sujay Kaushal.

Electronic supplementary material The online version of this article (doi:10.1007/s10533-017-0330-0) contains supplementary material, which is available to authorized users.

B. Hong · D. P. Swaney $(\bowtie)$

Department of Ecology and Evolutionary Biology,

Cornell University, Corson Hall, Ithaca, NY 14853, USA

e-mail: dps1@cornell.edu

Present Address:

B. Hong

Division of Water Resources, North Carolina Department of Environmental Quality, 1611 Mail Service Center, Raleigh, NC 27699, USA

\footnotetext{
M. McCrackin · A. Svanbäck · C. Humborg ·

B. Gustafsson

Baltic Sea Centre, Stockholm University,

10691 Stockholm, Sweden
}

drainage basin ( -25 and $-40 \%$ respectively). The changes were due primarily to changes in mineral fertilizer use. Mineral fertilizers dominated inputs, at $57 \%$ of both NANI and NAPI in 2000, increasing to 68 and $70 \%$, respectively, by 2010 . Net food and feed imports declined over that period, corresponding to increased crop production; either fewer imports of food and feedstocks were required to feed humans and livestock, or more of these commodities were exported. A strong linear relationship exists between regional net nutrient inputs and riverine nutrient fluxes for both periods. About $17 \%$ of NANI and $4.7 \%$ of NAPI were exported to the sea in 2000; these relationships did not significantly differ from those for 2010. Changes in NANI from 2000 to 2010 across basins were directly proportional rather than linearly related to changes in total $\mathrm{N}$ (TN) fluxes to the sea (i.e.,

\footnotetext{
A. Yershova

Russian State Hydrometeorological University,

Malookhtinsky pr. 98, St. Petersburg, Russia 195196
}

\section{A. Pakhomau}

Central Research Institute for Complex Use of Water

Resources, Minsk, Belarus 
no change in NANI suggests no change in TN flux). Similarly, for all basins except those draining to the Baltic Proper, changes in NAPI were proportional to changes in total P (TP) fluxes. The Danish Straits decreased most between 2000 and 2010, where NANI and NAPI declined by 25 and $40 \%$, respectively, and corresponding fluxes of TN and TP declined 31 and $18 \%$, respectively. For the Baltic Proper, NAPI was relatively unchanged between 2000 and 2010, while riverine TP fluxes decreased $25 \%$, due possibly to lagged effects of fertilizer reduction resulting from socio-political changes in the early 1990s or improvements in sewage treatment capabilities. For most regions, further reductions in NANI and NAPI could be achieved by more efficient production and greater substitution of manure for imported mineral fertilizers.

Keywords NANI $\cdot$ NAPI $\cdot$ Anthropogenic nutrient inputs - Baltic watershed $\cdot$ Total nitrogen $\cdot$ Total phosphorus

\section{Introduction}

In the modern, developed world, nitrogen $(\mathrm{N})$ and phosphorus (P) fluxes from land to coastal waters are dominated by anthropogenic sources (Howarth et al. 1996, 2012; NRC 2000; Bennett et al. 2001; Galloway et al. 2004; Howarth 2008). Impacts of nutrient loading on coastal water quality and ecological function are significant and associated with eutrophication, hypoxic ("dead") zones, harmful algal bloom development, and declines in the economic value and ecosystem services of coastal areas (Anderson et al. 2002; Smith 2003; Diaz and Rosenberg 2008). While magnitudes vary widely, both $\mathrm{N}$ and $\mathrm{P}$ loads can be largely attributed to agricultural sources and the waste streams from food consumption (Howarth et al. 1996, 2012; Han et al. 2011; Russell et al. 2008). In watersheds with substantial crop production, the regional exports of food and livestock feed that drive the economy are associated with inputs of fertilizer that can contribute to excess nutrient loads to regional waters. In watersheds with high population density or intensive livestock production whose food and feedstock demands exceed local production, imports needed to support these populations can also result in excess nutrient loading in the waste stream (Swaney et al. 2012a, b).

Eutrophication is a significant environmental pressure in the Baltic Sea, home to the world's largest hypoxic "dead" zone and persistent cyanobacteria blooms (Carstensen et al. 2014). Nutrient loads from the drainage basin to the sea have been welldocumented (Hong et al. 2012; HELCOM 2015); however, the international, transboundary nature of these nutrient loads complicate management efforts. A number of policies have sought to reduce land-based nutrient loads to the Baltic Sea, such as the European Union (EU) Water Framework Directive, the Nitrates Directive, and the Helsinki Commission (HELCOM) Baltic Sea Action Plan. While there has been progress in reducing TN and TP loads in the past few decades (HELCOM 2015), further actions are needed on land to fulfill the commitments of existing policy measures. To assess the progress toward eutrophication management goals, it is important to understand recent trends in nutrient use on land. Such understanding is especially needed given the social, political, and economic changes that have occurred in the past decades in the former Soviet-bloc countries located in the southern and eastern regions of the Baltic Sea basin.

Here we build on the work of Hong et al. (2012), who applied a well-established nutrient accounting method for net anthropogenic nitrogen inputs (NANI) and net anthropogenic phosphorus inputs (NAPI) to the Baltic Sea basin and found a strong linear relationship between the human-induced $\mathrm{N}$ and $\mathrm{P}$ inputs and riverine TN and TP fluxes for the year 2000 . We apply the NANI and NAPI framework to more recent data for the periods around 2000 and 2010 with three objectives; to explore changes in land-based $\mathrm{N}$ and $\mathrm{P}$ inputs between 2000 and 2010; to investigate the relationship between changes in net anthropogenic nutrient inputs and changes in riverine fluxes; and to estimate nutrient use efficiency in agriculture. First, we compare the major components of NANI and NAPI between 2000 and 2010 at sub-basin and sub-national scales. Second we examine the relationship between NANI and NAPI and the corresponding TN and TP fluxes in order to gain insight into primary factors controlling regional variation and temporal variation (between 2000 and 2010) of nutrient loading to the Baltic Sea. Lastly, we use NANI and NAPI accounting 
to understand the magnitude of nutrient demand by the crops and the current sources of nutrient inputs meeting this demand, thereby exploring the potential for a more effective nutrient management strategy.

\section{Materials and methods}

Study area

We performed our analysis on a total of 53 administrative accounting units within the Baltic Sea basin (42 NUTS2 for EU countries, 4 Belarus oblasts and 7 Russian oblasts; Fig. 1).

\section{Data collection}

The primary "data collection unit" used here is level two of the European Union's data collection system, organized by its Nomenclature of Territorial Units for Statistics (referred to as NUTS, http://ec.europa.eu/ eurostat/web/nuts/overview). Information compiled at the NUTS2 level from the EuroStat database together with additional regional information at the oblast level (Russia and Belarus; Belarus oblasts are also referred to as voblasts) are the basis of our estimates of regional variation of NANI and NAPI across the Baltic drainage basin.

NUTS2 level data for the European countries on annual crop production and areas, livestock numbers, population, and use of inorganic fertilizers were downloaded from the EuroStat website (http://ec. europa.eu/eurostat; Table 1). These data had missing values that were often more pronounced outside the 2008-2012 periods. For the years where the national level data were available but the sub-national values were missing, the sub-national values were estimated by assuming the same proportions obtained from the nearby years where both the national and sub-national data were available. Where possible, linear interpolations were made to estimate the values in the years with data gaps. When extrapolation was needed (i.e., periods without data available at both their beginning and end), the missing values were set to be the same as those in the closest available years, rather than assuming an increasing or decreasing trend. Finally, some gaps were filled by utilizing available data in other related categories (as an example, a missing number of heifers could be estimated from the sum of "heifers, for slaughter" and "heifers, not for slaughter", if both available). Datasets for Russian and Belarusian oblasts were collected from various sources and processed in a similar way (Table 1), as further described below.

NANI/NAPI calculation

NANI can be calculated as the sum of oxidized $\mathrm{N}$ deposition, fertilizer $\mathrm{N}$ application, agricultural $\mathrm{N}$ fixation and $\mathrm{N}$ in net food and feed imports. The net food and feed imports are, in turn, calculated as the sum of human and livestock $\mathrm{N}$ consumption (positive fluxes adding $\mathrm{N}$ to the area of interest) minus the sum of livestock and crop $\mathrm{N}$ production (negative fluxes removing $\mathrm{N}$ from the area of interest). The NAPI calculation is performed in a very similar way, though it is generally simpler than the NANI calculation because it is assumed that there is no (or very little) atmospheric $\mathrm{P}$ deposition, and there is no analog in $\mathrm{P}$ for agricultural $\mathrm{N}$ fixation. However, NAPI has an additional term, human non-food use of $\mathrm{P}$ (e.g., detergent). Below we describe the calculation of each component of NANI and NAPI in our study area.

\section{Atmospheric $N$ deposition}

Following previous work (Boyer et al. 2002; Howarth et al. 2006, 2012; Han and Allan 2008; Hong et al. 2011, 2012, 2013; Eriksson Hägg et al. 2012; Schaefer and Alber 2007), we considered the oxidized forms of atmospheric $\mathrm{N}$ deposition, since most reduced $\mathrm{N}$ deposition typically originates from nearby ammonia/ ammonium emissions redeposited on the same area of interest. While it is recognized that some forms of reduced nitrogen can travel greater distances when scavenged by atmospheric aerosols or precipitation, Eriksson Hägg et al. (2012) found no advantage in considering $\mathrm{NO}_{\mathrm{y}}+\mathrm{NH}_{\mathrm{x}}$ deposition over just $\mathrm{NO}_{\mathrm{y}}$ deposition in their study of Swedish catchments. It is important to distinguish between the composition of long distance (i.e., new sources) and local sources (i.e., recycled nitrogen). However, as a proxy of the reduced $\mathrm{N}$ that arises from non-local sources, for each watershed in the region we estimated the reduced $\mathrm{N}$ from external sources (i.e., long distance transport from sources outside the country containing the river basin) using EMEP country-grid source receptor estimates (http://www.emep.int/mscw/mscw_srdata. 
Fig. 1 NUTS2 and oblasts within the Baltic Sea basin (BY Belarus, $C Z$ Czech Republic, $D E$ Germany, $D K$ Denmark, $E E$ Estonia, $F I$ Finland, $L T$ Lithuania, $L V$ Latvia, $P L$ Poland, $R U$ Russia, $S E$ Sweden, $S K$ Slovakia). Seven basin names are indicated as: $B B$ Bothnian Bay, BP Baltic Proper, $B S$ Bothnian Sea, $D S$ Danish Straits, GF Gulf of Finland, GR Gulf of Riga, KT Kattegat

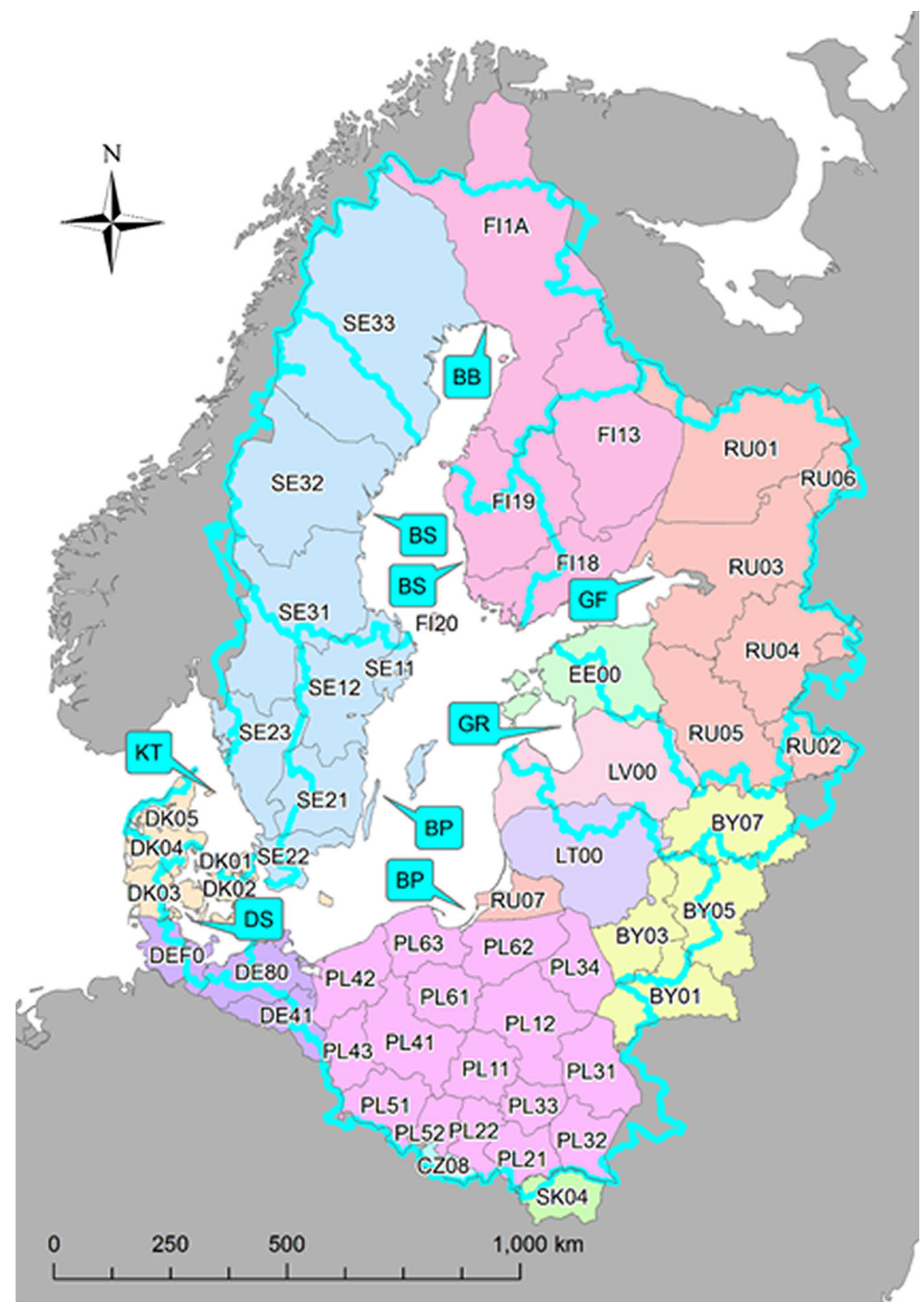

html\#GridData), and summed these over all watersheds in each of the seven Baltic catchment regions. The resulting basin-scale ratio of $\mathrm{NHx} / \mathrm{NOy}$ deposition was used to estimate the contribution of reduced $\mathrm{N}$ deposition for the seven Baltic regions (Tables S10S11, supplemental materials). Comparing NANI without NHx to NANI with all NHx and to NANI with nonlocal NHx had no significant impact on our analysis (Fig. S2, supplemental materials), so we present NANI with the contribution of NOy deposition only in the main text.

Oxidized $\mathrm{N}$ deposition estimates were downloaded from the EMEP model simulation output available at http://www.emep.int/ with a grid resolution of $50 \mathrm{~km} \times 50 \mathrm{~km}$. EMEP deposition estimates are updated periodically; we used the most recent version 
Table 1 Source of data used in this study

\begin{tabular}{|c|c|c|}
\hline Variable & Region & Data source \\
\hline $\mathrm{N}$ deposition & All regions & EMEP \\
\hline \multirow[t]{3}{*}{ Use of inorganic fertilizers } & EU countries & EuroStat (aei_fm_usefert) \\
\hline & Russia & International Plant Nutrition Institute \\
\hline & Belarus & $\begin{array}{l}\text { Statistical Yearbook of Belarus (National Statistical Committee of the } \\
\text { Republic of Belarus 2013, 2015) }\end{array}$ \\
\hline \multirow[t]{3}{*}{ Crop areas } & EU countries & EuroStat (ef_lu_ovcropaa, ef_lu_ovcropesu, ef_oluaareg, ef_oluecsreg) \\
\hline & Russia & $\begin{array}{l}\text { Statistical Yearbook of Russia (Russian Federation Federal State Statistical } \\
\text { Service 1999-2015) }\end{array}$ \\
\hline & Belarus & $\begin{array}{l}\text { Statistical Yearbook of Belarus (National Statistical Committee of the } \\
\text { Republic of Belarus 2013, 2015) }\end{array}$ \\
\hline \multirow[t]{3}{*}{ Population } & EU countries & EuroStat (demo_r_d2jan) \\
\hline & Russia & $\begin{array}{l}\text { Russian Federation Federal State Statistics Service database tables, FSSS } \\
\quad(2008,2001-2013)\end{array}$ \\
\hline & Belarus & BelarusInfo database, Belstat $(2001,2010-2015)$ \\
\hline \multirow[t]{3}{*}{ Livestock numbers } & EU countries & EuroStat (agr_r_animal, ef_ls_ovaareg, ef_olsaareg) \\
\hline & Russia & $\begin{array}{l}\text { Statistical Yearbook of Russia (Russian Federation Federal State Statistical } \\
\text { Service 1999-2015), FSSS website (2015; http://www.gks.ru/) }\end{array}$ \\
\hline & Belarus & Belstat (Belstat 2009-2015) \\
\hline \multirow[t]{3}{*}{ Crop production } & EU countries & $\begin{array}{l}\text { EuroStat (agr_r_crops, ef_lu_ovcropaa, ef_lu_ovcropesu, ef_oluaareg, } \\
\text { ef_oluecsreg) }\end{array}$ \\
\hline & Russia & $\begin{array}{l}\text { Statistical Yearbook of Russia (Russian Federation Federal State Statistical } \\
\text { Service 1999-2015), FSSS website (2015; http://www.gks.ru/) }\end{array}$ \\
\hline & Belarus & $\begin{array}{l}\text { Statistical Yearbooks (Agriculture of the Republic of Belarus 2001, 2002, } \\
\text { 2009-2015) }\end{array}$ \\
\hline
\end{tabular}

available at the time of our study for each year (v2015 for the 2000-2012 estimates and v2006 for the 1998-1999 estimates). A GIS tool, the Geospatial Modelling Environment (freeware compatible with ArcGIS, available at http://www.spatialecology.com/ gme/), was used to overlay the EMEP grid and NUTS2/oblasts maps and calculate the annual areaweighted averages of oxidized $\mathrm{N}$ deposition.

\section{Fertilizer $N$ and $P$ application}

For accounting units within the EU, data on inorganic fertilizer $\mathrm{N}$ and $\mathrm{P}$ use were obtained from the "aei_fm_usefert" table of the EuroStat database (Table 1). NUTS2 level data were often missing outside the 2008-2012 period, and only the national level fertilizer data were available for Denmark and Germany. When it was not possible to estimate the allocation of the national level fertilizer use among its
NUTS2 areas from the available EuroStat datasets, the allocation was performed based on the relative use of inorganic fertilizer in 2000 as estimated by Joint Research Centre (EU-JRC) in Institute for Environment and Sustainability (ISPRA) (Grizzetti et al. 2007) and used in the previous NANI/NAPI analysis by Hong et al. (2012). For regions outside the EU (i.e., Russia and Belarus), we obtained oblast-level estimates from other sources. Data on N and P in mineral fertilizer for Russian oblasts (Leningrad, Kaliningrad, Karelia, Pskov and Novgorod) for the years 2008-2015 were made available by the International Plant Nutrition Institute (S. Ivanova, IPNI, personal communication). Estimates of $\mathrm{N}$ and $\mathrm{P}$ in mineral fertilizer in Belarus oblasts were obtained from official Belarus agricultural statistics for the years 2000-2001 and 2005-2014 (National Statistical Committee of the Republic of Belarus 2013, 2015). A factor of 0.4266 was used to convert from the reported $\mathrm{P}_{2} \mathrm{O}_{5}$ values to $\mathrm{P}$ equivalents. 


\section{Agricultural N fixation}

Agricultural $\mathrm{N}$ fixation may be estimated by multiplying each $\mathrm{N}$ fixing crop area by its $\mathrm{N}$ fixation rate and summing over all crops. Alternatively, agricultural $\mathrm{N}$ fixation can be estimated from reported yields of $\mathrm{N}$ fixing crops and proportions of $\mathrm{N}$ production attributable to $\mathrm{N}$ fixation (Hong et al. 2013). In this study we used the area-based approach for consistency with the previous Hong et al. (2012) analysis and because yield information was not readily available for all the N fixing crops. The NUTS2 level N fixing crop areas for the EU countries were obtained from several tables ("ef_lu_ovcropaa", "ef_lu_ovcropesu", "ef_oluaareg" and "ef_oluecsreg") of the EuroStat database. Oblast-level crop areas for N fixing crops in Russia were obtained from the Russian Federation Federal State Statistical Service (FSSS) (2015). For Belarus, areas of $\mathrm{N}$ fixing crops, including legumes and grasses, were obtained from official Belarus agricultural statistics for the years (National Statistical Committee of the Republic of Belarus 2013, 2015). The country-specific $\mathrm{N}$ fixation rates corresponding to each crop type were obtained from Hong et al. (2012) (Table S1, supplemental materials).

\section{Net food and feed imports}

In most NANI and NAPI calculations, net food and feed imports are estimated as the difference between the consumption of food and feed by human and livestock and the production from crops and livestock. If the consumption of food and feed is greater than the local agricultural production, the $\mathrm{N}$ and $\mathrm{P}$ in deficit is assumed to be met by imported food and feed from outside the area of interest and consumed by the human and livestock. If local agricultural production exceeds demand, it is assumed to be exported, and so there will be a net export of $\mathrm{N}$ and $\mathrm{P}$ from the region.

Human N and P consumption Population data for the European countries were obtained from the "demo_r_d2jan" table of the EuroStat database, and were multiplied by the country-specific human $\mathrm{N}$ and $\mathrm{P}$ intake rates (Table S2, supplemental materials; Hong et al. 2012) to estimate human $\mathrm{N}$ and $\mathrm{P}$ consumption. Population data for Belarus are from the Statistical Yearbook Regions of the Republic of Belarus (Belstat 2001, 2010-2015) and the
BelarusInfo database (http://www.belstat.gov.by/ofit sialnaya-statistika/bazy-dannyh/baza-dannyh-belarus info/). Population data for Russia are from the Russian State Statistical Service database (FSSS 2008, 2001-2013). Following Hong et al. (2012), the N:P ratio of human intake was assumed to be 5. This consumption estimate does not include non-food use of $\mathrm{P}$, which was separately accounted for as described below.

Livestock $N$ and $P$ consumption and production The "agr_r_animal" table of the EuroStat database contains NUTS2 level livestock numbers, except for the poultry numbers that are available in "ef_ls_ovaareg" and "ef_olsaareg" (Table 1). Livestock data for Russia are available in the Statistical Yearbooks of Russia (1999-2015) and the FSSS website. For Belarus, data were obtained from the Statistical Yearbook, Agriculture of the Republic of Belarus (Belstat 2009-2015). Livestock N and P consumption is calculated as the product of livestock numbers and the intake coefficients for the corresponding livestock groups (Table S3, supplemental materials). Livestock $\mathrm{N}$ and $\mathrm{P}$ excretion is calculated in the same way from the excretion coefficients (Table S4, supplemental materials), and the difference between these two (with the $10 \%$ processing loss) gives $\mathrm{N}$ and $\mathrm{P}$ in livestock products. The processing loss also represents the parts of the animals that are not edible (e.g., bones) and thus not consumed as food. The animal loss term, like the crop loss term, is often assumed to be $10 \%$ in nutrient budget calculation, while its variation over space, time, and type is subject to considerable uncertainty (Hong et al. 2012). An alternative way of estimating livestock production is to use animal products data (e.g., milk, eggs, meat, etc.) with their nutrient contents. Hong et al. (2011) calculated N budgets for the US watersheds using both approaches and obtained comparable results. Livestock $\mathrm{N}$ parameters were taken from Hong et al. (2012) with little modification, except that the "goats" livestock category that was previously missing has been added (Hong et al. 2013). In the previous budget calculation for the Baltic (Hong et al. 2012), livestock intake and excretion rates were assumed constant over time. However, in this study, annual variation of these rates over the 1995-2014 periods was approximated from the annual variation of $\mathrm{N}$ excretion rates obtained from 
the National Inventory Submissions report (2015) of the United Nations Framework Convention on Climate Change, by assuming the same fractional deviation from the mean. In Hong et al. (2012), livestock $\mathrm{P}$ intake and excretion values were estimated by assuming animal-specific N:P ratios $(6,3,4$ and 5 for cattle, pigs, poultry and sheep, respectively) based on Claesson and Steineck (1991). Further literature search (Sheldrick et al. 2003; ASAE 2005; OECD 2007a, b; Tybirk et al. 2013) resulted in varying degrees of uncertainty ranges for these parameters, as summarized in Table 2. Although N:P for intake did not necessarily equal that for excretion, it was generally close. We held the ratios constant and updated our best estimates to those values shown in Table 2.

Crop $N$ and $P$ production The $\mathrm{N}$ and $\mathrm{P}$ in crop production are calculated as the product of the mass of harvested crops and their N and P contents. Most of the crops in the EuroStat table "agr_r_crops" containing NUTS2-level crop harvest data (Table S5, supplemental materials) are found in the JRC crop list used by Hong et al. (2012). For those crops, nutrient contents were taken from Hong et al. (2012). The nutrient contents of some crops that were not included in the previous study (rice, cotton, tobacco and olives), mostly in minor proportion, were obtained from Lander et al. (1998) and Hong et al. (2013). Crops with the EuroStat code starting with "C" in
Table S5 (supplemental materials) have NUTS2-level harvested crop production data available (in thousand tonnes). Productions of the crops without the harvest data, mostly different types of grasslands (permanent, temporary, fallow, etc.; Table S5) and minor crops, were estimated from the crop areas (obtained from the EuroStat database "ef_lu_ovcropaa", "ef_lu_ovcropesu", "ef_oluaareg" and "ef_oluecsreg") and available yield information. Crop data for Russia are from FSSS (2015), and from the Statistical Yearbooks, Agriculture of the Republic of Belarus (2001, 2002, 2009-2015) for Belarus. Distribution of crop production to human (versus livestock) and processing losses are taken from Hong et al. (2012, 2013). Although some crops that are not consumed as food or feed (e.g., cotton and tobacco) are included in this calculation, they only comprise small portions of the overall budgets.

\section{Non-food use of $P$ by humans}

The non-food use of $\mathrm{P}$ by human (e.g., in detergents) is a relatively small term in the overall nutrient budget (e.g., Han et al. 2011). It is often combined with the $\mathrm{P}$ in food consumption described above and becomes part of the "net (non-)food and feed imports." A coefficient of $0.35 \mathrm{~kg}-\mathrm{P} / \mathrm{capita} / \mathrm{year}$ was applied to estimate the human non-food use of P (Hong et al. 2012; Rybicki 1997; Han et al. 2011). There may be substantial spatial and temporal variability in this

Table 2 Uncertainty ranges of the N:P ratios for the livestock intake and excretion parameters and the best estimates used in this study

\begin{tabular}{|c|c|c|c|c|c|}
\hline $\mathrm{N}: \mathrm{P}$ excretion (mass) & ASAE (2005) & Sheldrick et al. (2003) & OECD $(2007 a, b)$ & Tybirk et al. (2013) & Best estimate \\
\hline Poultry & & & & & 4 \\
\hline Broiler & 3.4 & $4.4-7.5$ & 4 & 4.5 & \\
\hline Layer & 3.2 & $2.7-3.9$ & 3.5 & 4.4 & \\
\hline Cattle & & & & & 6 \\
\hline Beef & 7.5 & $3.1-6.6$ & $6.2-9.4$ & & \\
\hline Dairy & 5.8 & $5.9-7.5$ & 6.1 & 7.2 & \\
\hline Pig & & & & & 4.5 \\
\hline Sow & $3.6-4.6$ & $2.9-4.3$ & 3.7 & 4.6 & \\
\hline Boar & 2.9 & 3.3 & 3.8 & & \\
\hline Goat & & $4.4-11.1$ & 5.3 & & 6 \\
\hline Sheep & & $4.3-11.1$ & $4.5-7$ & & 5 \\
\hline Horse & $4.7-6.9$ & $4.9-5.6$ & 5.5 & & 6.1 \\
\hline
\end{tabular}


estimate, as the use of laundry and dish-washing products has evolved differently among different countries within the Baltic basin.

\section{Manure $\mathrm{N}$ and $\mathrm{P}$ application}

Manure is not an explicit term of the NANI/NAPI calculation, as manure $\mathrm{N}$ and $\mathrm{P}$ production from animals and their application to crops are considered as internal fluxes (as are the ammonia/ammonium emissions and their redeposition; see oxidized $\mathrm{N}$ deposition section above). However, we estimated manure $\mathrm{N}$ and $\mathrm{P}$ fluxes in this study to better understand the potential magnitude of livestock $\mathrm{N}$ and $\mathrm{P}$ excretion that can meet the crop nutrient demands. Three coefficients are applied to convert livestock $\mathrm{N}$ and $\mathrm{P}$ excretion (see livestock $\mathrm{N}$ and $\mathrm{P}$ consumption and production section above) to manure $\mathrm{N}$ and $\mathrm{P}$ application: (1) fraction of livestock excretion collected in-house for manure production, estimated from the livestock excretion allocated to non-pasturelands (National Inventory Submissions report of the UN Framework Convention on Climate Change, http://unfccc.int/national_reports/annex_i_ghg_inven tories/national_inventories_submissions/items/8108. php), (2) fraction of livestock excretion (collected inhouse) converted into manure, estimated from the country-specific volatilization and leaching losses during the in-house manure production (Oenema et al. 2007) (Table S6, supplemental materials), and (3) fraction of manure (produced in-house) applied to croplands of interest. Note that the last parameter was set to one in this whole-watershed based analysis, but it may be refined depending on how the accounting boundary is defined (e.g., utilized agricultural area/ arable lands only).

Comparison with basin-wide riverine $\mathrm{N}$ and $\mathrm{P}$ exports

To obtain the watershed average of NANI, NAPI, or a constituent variable $\left(\mathrm{V}_{\mathrm{j}}\right)$ for each of the Baltic basin (indexed $\mathrm{j}$ ), values $\left(\mathrm{V}_{\mathrm{ij}}\right)$ for each administrative accounting unit region (i), expressed per area of the accounting unit ( $\mathrm{kg} \mathrm{N}, \mathrm{P} \mathrm{km}^{-2}$ year $\left.^{-1}\right)$, are multiplied by the area that falls within the drainage basin $\left(a_{i j}\right)$, summed over all contributing regions, and divided by the sum of the contributing areas:
$V_{j}=\frac{\sum_{i=1}^{n_{j}} a_{i j} V_{i j}}{\sum_{i=1}^{n_{j}} a_{i j}}$

In the case of complete coverage, the sum of the contributing areas would equal the area the entire Baltic drainage basin; in fact, it is a little over $97 \%$ of the $1,729,500 \mathrm{~km}^{2}$ comprising the drainage areas of the nine major Baltic basins (Archipelago Sea, Baltic Proper, Bothnian Bay, Bothnian Sea, Gulf of Finland, Gulf of Riga, Kattegat, The Sounds, and Western Baltic) described in the latest HELCOM pollution compilation PLC5.5 (HELCOM 2015). The matrix of $a_{i j}$ values can be found in the supplemental materials, Table S7.

For each of nine basins, total $\mathrm{N}(\mathrm{TN})$ and total $\mathrm{P}$ (TP) fluxes were obtained from HELCOM (2015; http://www.helcom.fi/baltic-sea-trends/indicators/ inputs-of-nitrogen-and-phosphorus-to-the-basins/ data-description-and-confidence/). Some of the neighboring basins in HELCOM (2015) were aggregated (e.g., Archipelago Sea + Bothnian Sea to Bothnian Sea; The Sounds + Western Baltic to Danish Straits) to facilitate comparison with Hong et al. (2012) and to avoid outlier behavior of small basins. The resulting categorization of 7 basins (Fig. 1) and their watersheds is consistent with some earlier studies. As noted in Hong et al. (2012), the data set incorporates nutrient fluxes from major monitored rivers as well as partially monitored or unmonitored coastal areas. The 217 rivers drain approximately $86 \%$ of the total catchment area and 24 partially monitored or unmonitored coastal areas, composed of many small streams, drain approximately $13 \%$. These areas were aggregated together to include both the monitored and unmonitored areas, and nutrient flux estimation was made based on the data available in small monitored streams.

\section{Results and discussion}

Spatial variation of NANI, NAPI and their components in 2010

NANI and NAPI in 2010 showed a strong latitudinal gradient (Fig. 2). NUTS2 areas in Denmark and Poland, as well as the oblasts in Belarus, had the highest per-area anthropogenic net $\mathrm{N}$ and $\mathrm{P}$ inputs. 


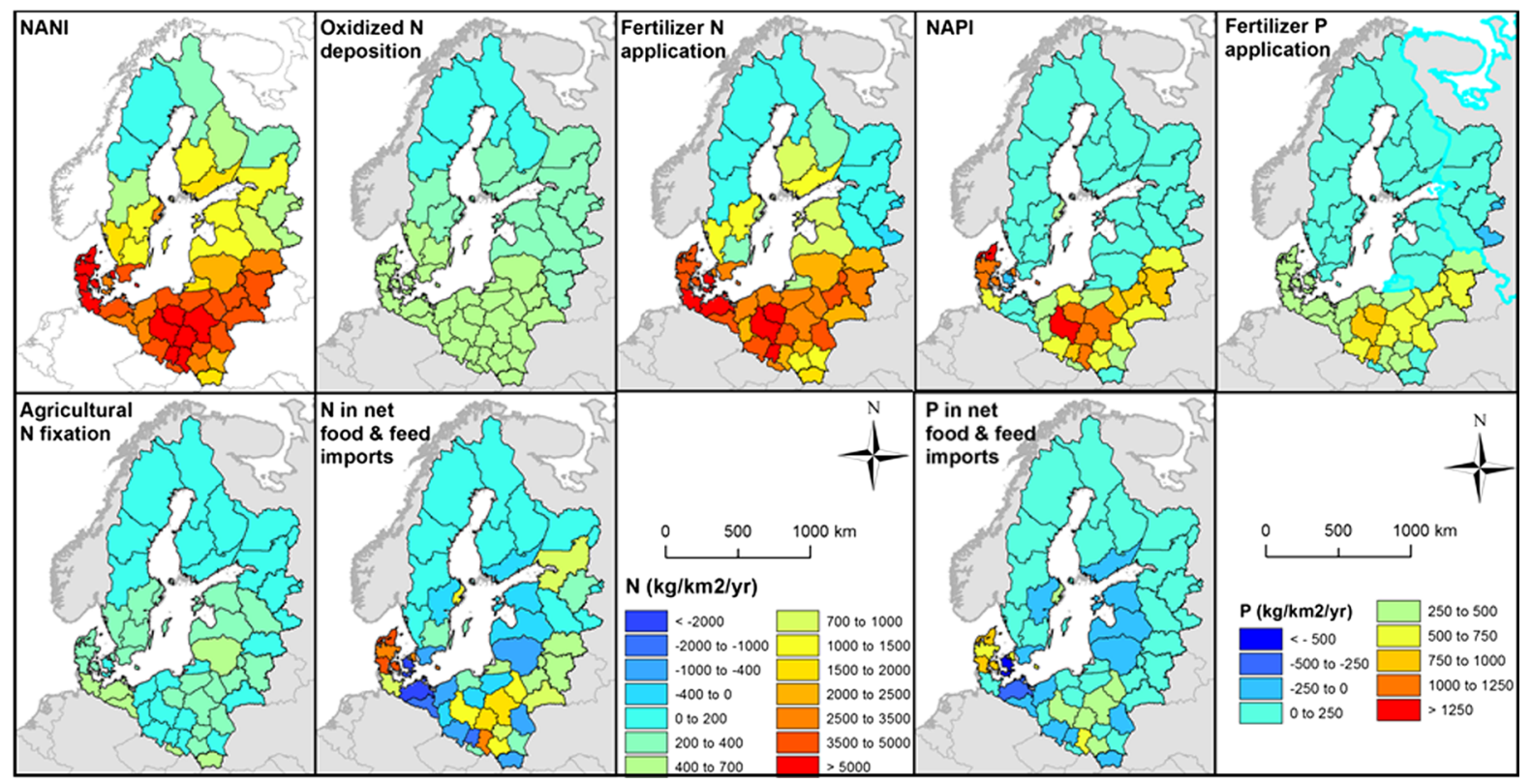

Fig. 2 NANI (kg-N/km²/year), NAPI (kg-P/km²/year) and their components in 2010 (2008-2012 average) at the NUTS2 and oblast level

These spatial patterns were primarily driven by fertilizer application to cropland and so correspond to the north-south gradient of agriculture, which represents a much higher proportion of land use with more intensive production in the southern Baltic drainage than in the north. Atmospheric deposition of oxidized $\mathrm{N}$ and agricultural fixation were relatively small during the same period. Deposition estimates obtained from the EMEP simulation output are higher in the south than the north, potentially reflecting the increased density of emission sources in the south, although bulk of NOx emissions may not be locally deposited. Net food and feed imports were either highly positive or highly negative in the southern Baltic NUTS2 areas, reflecting the intensity of net production or consumption in these relatively populous agricultural regions. Northern Baltic areas, on the other hand, showed relatively low or negative net food and feed imports due to their lower population density and lower agricultural activity.

Spatio-temporal trends in NANI, NAPI and their components, 2000-2010

Although the latitudinal variations in nutrients are persistent over time, spatial variation of the change in nutrient inputs between 2000 and 2010 exhibits different features than the basic north-south variations that dominate the spatial pattern for a single period. Figure 3, which shows these differences expressed as a percentage increase or decrease relative to 2000 , indicates that NANI shows modest decreases across Sweden and Finland, but patchy regions of modest increases or decreases elsewhere. Trends in NAPI are similar, but with sharper increasing trends in some areas, notably Belarus, Latvia and Estonia, associated with large increases in $\mathrm{P}$ fertilizer application and $\mathrm{P}$ in net food and feed imports during the period. Sharp decreases in net food and feed imports of nutrients, notably in some areas of Poland, indicate regions in which the $\mathrm{N}$ or $\mathrm{P}$ in local crop production has increased significantly relative to human and livestock consumption. This trend could have been confounded by changing diet and increasing meat and dietary consumption in this area; this issue was not addressed in our current study, in which human intake rates were not changed over time and differences in diet pattern between rural and urban residents were not explored. Variation in the change of livestock numbers within the Baltic Basin also contributed to the complex spatial pattern of food and feed change. For example, although livestock excretion and production are estimated to have decreased from 2000 to 2010 in the agriculturally intensive countries like Denmark and 


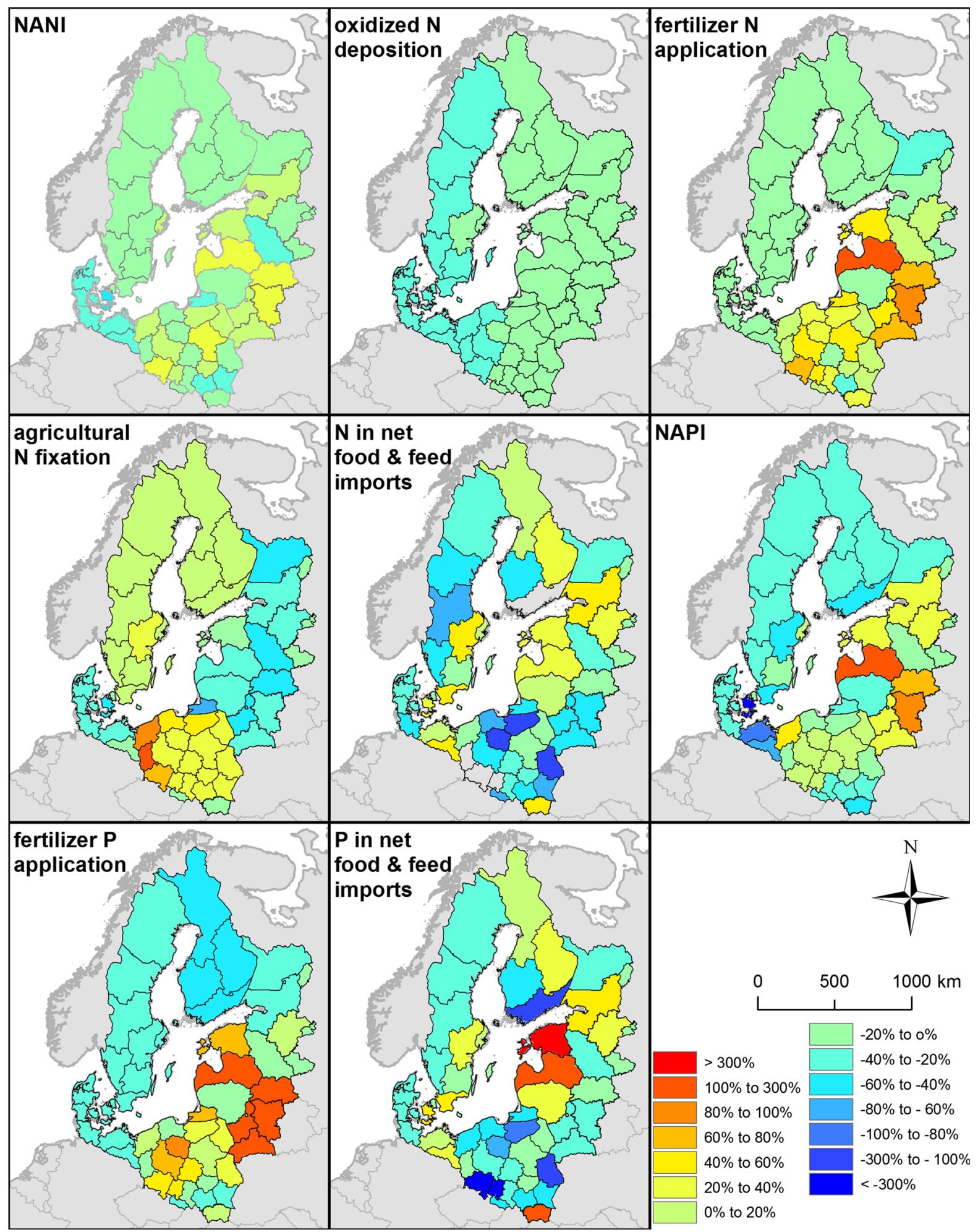

Fig. 3 Percent change in NANI, NAPI, and their components from 2000 (1998-2002 average) to 2010 (2008-2012 average) at the NUTS2 and oblast level. Hot and cool colors denote increases and decreases, respectively 
Poland and in many former EU countries, $\mathrm{N}$ and $\mathrm{P}$ in livestock products appear to have increased slightly in the new EU member states (Estonia, Latvia and Lithuania). This slight increase is the result of greater changes within various livestock groups; decreases in bovine and pig products were compensated by increases in poultry products in Latvia and Lithuania. Shifts in cropping have resulted in some increases in agricultural $\mathrm{N}$ fixation in Sweden and Finland (due to slight increases in forage and pulses, respectively), stronger increases in Poland (pulses and pasture), and decreases elsewhere. Oxidized $\mathrm{N}$ deposition has declined throughout the Baltic basin, with the greatest decreases $(20-40 \%)$ in the western half of the basin (Sweden, Denmark, Germany) and smaller decreases (0-20\%) elsewhere, largely reflecting different emission reduction targets among countries (EEA 2015).

The relationship between NANI/NAPI and riverine TN/TP fluxes at the basin scale remained strong (Figs. S1a,b) as previously demonstrated in Hong et al. (2012). The slope of the linear NANI versus TN flux relationship for 2000 estimated from the NUTS2/ oblast-level data (1998-2002 averages) (Fig. S1a, black line) increased slightly, but not significantly, from that of Hong et al. (2012; brown line) which was developed based on average fluxes for the period 1994-2006. Partly due to parameter refinements (e.g., updated $\mathrm{N}: \mathrm{P}$ ratios for the livestock intake and excretion rates; Table 2; Tables S3, S4, supplemental materials) and partly due to changes in riverine TP flux estimates, the slope of the NAPI versus TP flux regression line has increased significantly (Fig. S1b, black line) compared to the previous estimation (brown line), but yielded similar $\mathrm{R}^{2}$ values. All regression lines are statistically significant. Intercepts of the regressions from Hong et al. (2012) are not significantly different from those of the present study, indicating that non-NANI/NAPI driven (background) nutrient flux estimates are the same in both cases. Slopes of the regressions suggest that about $17 \%$ of NANI and $4.7 \%$ of NAPI were exported to the sea in 2000. Previous studies reported similar percent export values: about 10-30\% for nitrogen (Howarth et al. 2006, 2012; Eriksson Hägg et al. 2012; Han et al. 2009; Han and Allan 2008; Schaefer and Alber 2007; Boyer et al. 2002) and 2-10\% for phosphorus (Russell et al. 2008; Han et al. 2011; Zhang et al. 2015). The nutrient accounting approach can be used to estimate nutrient retention, which has been reported to vary across individual watersheds, regions, and continents (Garnier et al. 2015). Its variation has been shown to be strongly correlated with climatic and hydrologic conditions; for example, in Europe the fraction of NANI exported as riverine fluxes is lowest in Mediterranean watersheds, highest in Nordic watersheds, and in-between in temperate watersheds (Romero et al. 2016; Billen et al. 2011).

Figure $4 \mathrm{a}$ compares the relationships between NANI and TN flux for the 5-year averages centered on 2000 (black symbols) and 2010 (blue symbols) based on NUTS2/oblast-level data and PLC5.5 riverine and coastal TN estimates aggregated to the drainage area of the Baltic basins; it is evident that similar linear relationships apply between NANI and TN fluxes across watersheds for both periods (the slopes and intercepts are not significantly different from each other). However, if the differences in both NANI and the TN fluxes between the two periods are plotted against each other (Fig. 4b) it is clear that the absolute change in riverine $\mathrm{TN}$ fluxes responds directly to the corresponding absolute changes in NANI between the two periods. The slope of the regression line is statistically different from zero, but the intercept is not (Table S9, supplemental materials) indicating that the change in TN flux is directly proportional to (i.e., can be expressed as some fraction of) that of NANI. This, together with statistically indistinguishable slopes of the NANI vs TN relationship in both periods indicates that changes in TN flux are not due to changes in delivery efficiency or other factors, but in the values of NANI itself.

For NAPI and TP, nearly identical linear relationships (slopes and intercepts are not significantly different) apply to each 5-year period average (Fig. 4c). While the decadal differences of NAPI correspond to the differences of TP fluxes for most watersheds (Fig. 4d), the relationship is not statistically significant $(p>0.05)$ due to the outlier behavior of the Baltic Proper, BP, which exhibits a relatively large decline in TP flux corresponding to an apparently small change in NAPI over the same period. This is in contrast to $\mathrm{TN}$ in $\mathrm{BP}$, which declines slightly in accordance with the slight decline in NANI. The reason for this discrepancy is unclear at present, but some insights can be gained by looking at the relationships between individual components of NANI and NAPI and their corresponding waterborne TN and TP fluxes (Table S9, supplemental materials). 


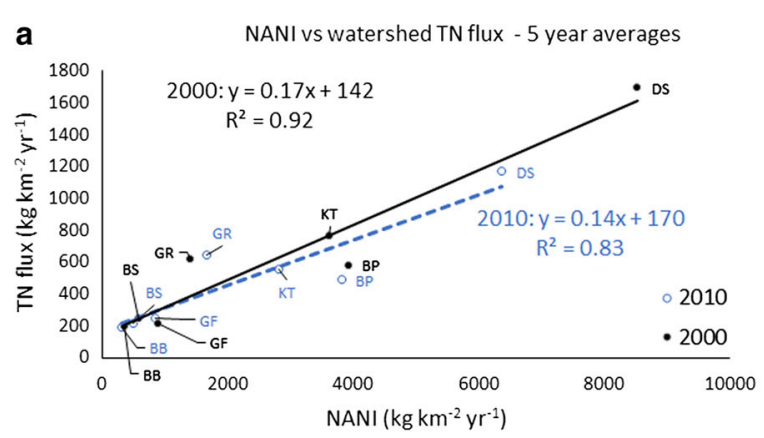

C

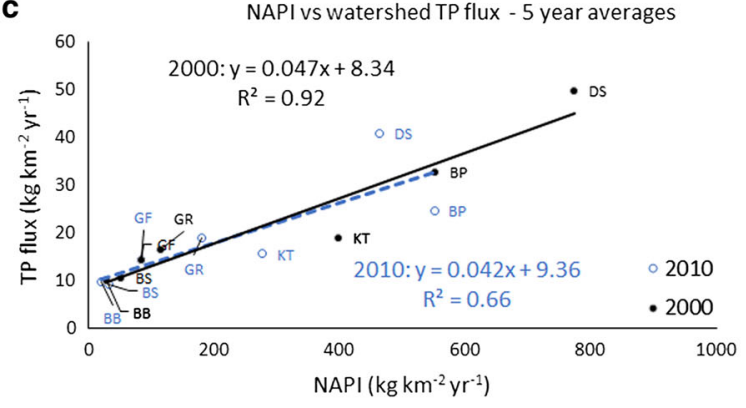

Fig. 4 Relationships between NANI and TN fluxes for the years 2000 and 2010 (a) and their decadal changes (b) and those for the NAPI and TP fluxes $(\mathbf{c}, \mathbf{d})$. Waterborne fluxes are the total of riverine fluxes from monitored rivers in each of the basins and estimates for unmonitored coastal regions, based on data from

Fertilizer $\mathrm{N}$ and $\mathrm{P}$ is as strong a predictor as is NANI and NAPI for periods centered on 2000 and 2010, which is consistent with it being the dominant component of the overall nutrient budget (Table S9, supplemental materials). While the relationship between the change in $\mathrm{N}$ fertilizer and $\mathrm{TN}$ flux is highly significant, the relationship between $\mathrm{P}$ fertilizer and TP flux over the same period is not. Change in both $\mathrm{N}$ and $\mathrm{P}$ in net food and feed imports between 2000 and 2010 is significantly related to corresponding $\mathrm{TN}$ and TP fluxes across basins, respectively, but within a given period shows weaker relationships with these fluxes than does fertilizer (Table S9). This is attributable in part to the inherent spatial variability of net food and feed and its individual components.

\section{Components of NANI and NAPI}

Figure 5 shows the dominance of mineral fertilizer $\mathrm{N}$ and $\mathrm{P}$ (light orange bar) in most regions of the Baltic, particularly the southern agricultural regions. Net food and feed imports (dark orange bar) are also important, primarily in the populous south. NANI and NAPI are
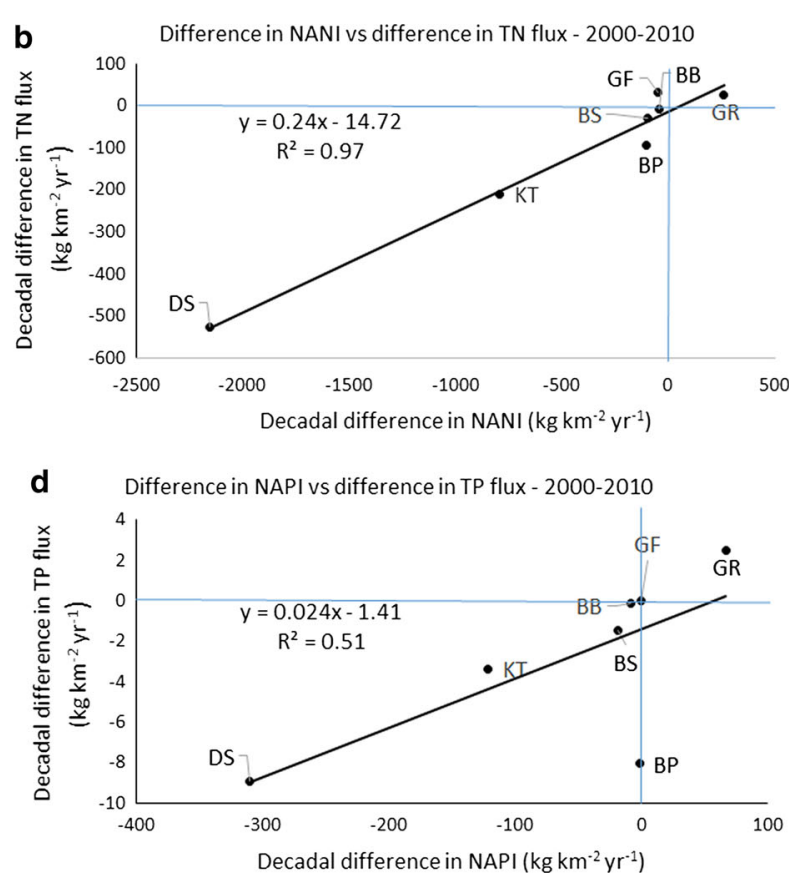

PLC5.5 (Helcom 2015). NANI and NAPI are calculated in this study from NUTS2/oblasts data. $B B$ Bothnian Bay, $B P$ Baltic Proper, $B S$ Bothnian Sea, DS Danish Straits, $G F$ Gulf of Finland, GR Gulf of Riga, KT Kattegat

much smaller overall in the forest regions of the north, where atmospheric $\mathrm{N}$ deposition (blue bar) can represent a significant contribution to NANI. As seen above, the spatial variation of watershed $\mathrm{N}$ and $\mathrm{P}$ export (blue lines) across watersheds corresponds to the pattern of NANI and NAPI over the same regions. While the relative magnitudes of regional NANI and NAPI changed little between 2000 and 2010, some important shifts can be seen. NANI and NAPI declined in the watersheds of both the Kattegat and Danish straits, as did corresponding fluxes of TN and TP. Danish policy to reduce $\mathrm{N}$ surpluses on farms and the associated reductions in $\mathrm{N}$ loads to aquatic environments in these regions is well documented (Dalgaard et al. 2014). Some increase in NANI and NAPI occurred in the Gulf of Riga, driven by increases in fertilizer in the region (from 728 to $1181 \mathrm{~kg} \mathrm{~km}^{-2}$ watershed area year ${ }^{-1}$ for $\mathrm{N}$, and $84-166 \mathrm{~kg} \mathrm{~km}^{-2}$ watershed area year ${ }^{-1}$ for $\mathrm{P}$ ), but with little change evident in watershed fluxes. As noted above, NANI and NAPI changed little in the BP drainage, but while TN fluxes changed little, TP fluxes declined. While it is possible that the mismatch between TP and NAPI 

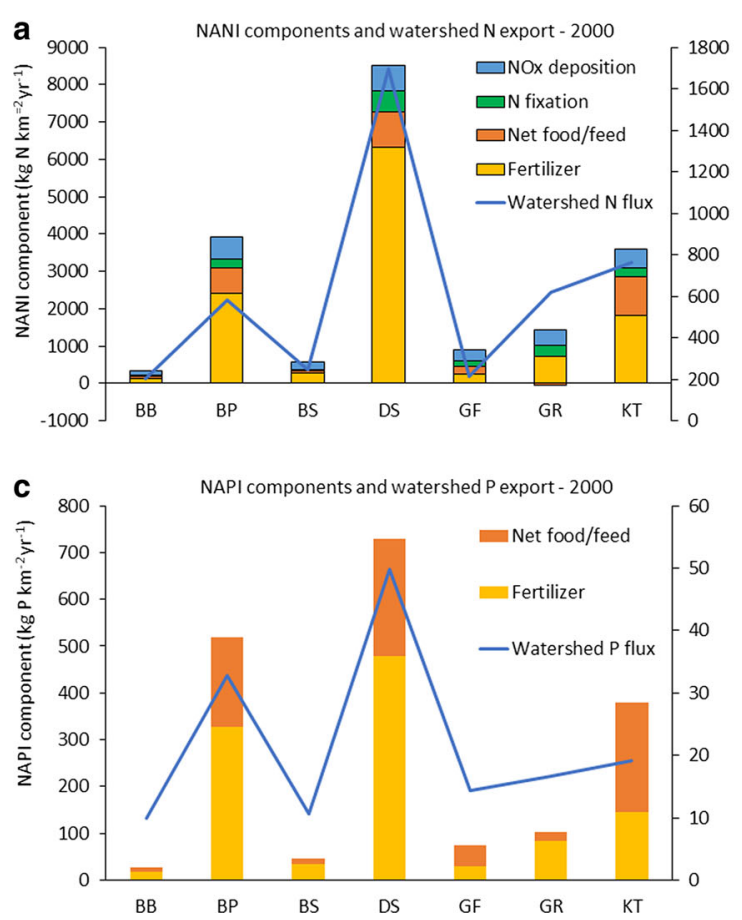

Fig. 5 Components of NANI (a, b) and NAPI (c, d) for watersheds of the major Baltic basins in 2000 (a, c) and 2010 (b, d). Mineral fertilizer inputs are the dominant term for both $\mathrm{N}$ and $\mathrm{P}$ in agricultural regions, including the watersheds of BP, DS,

over the period is due to parameter or data errors in some of the regional watersheds draining to the BP (e.g., uncaptured decline in the per capita use of $\mathrm{P}$ in detergents), it is also possible that there are data quality issues related to TP fluxes. A third possibility is that the change in TP flux reflects reductions in $\mathrm{P}$ export associated with various factors, such as improvements in sewage treatment capabilities in Poland (Ilnicki 2014), evolution of the market of laundry and dishwashing powders, and the lagged effect of decreased fertilizer P use after the collapse of the Soviet Union in the early 1990s (Pastuszak et al. 2012). Due to uncertainties in data and accounting methods, it is somewhat challenging to accurately pinpoint the source(s) of unexplained deviations. Compared to the US and European countries where agricultural data are made available in a public domain with a standardized database format (Hong et al. 2011, 2012), data from Russia and Belarus tend to be scattered among different sources, often with greater gaps and uncertainties. Selection of specific accounting methods (e.g., area- vs yield-based $\mathrm{N}$ fixation
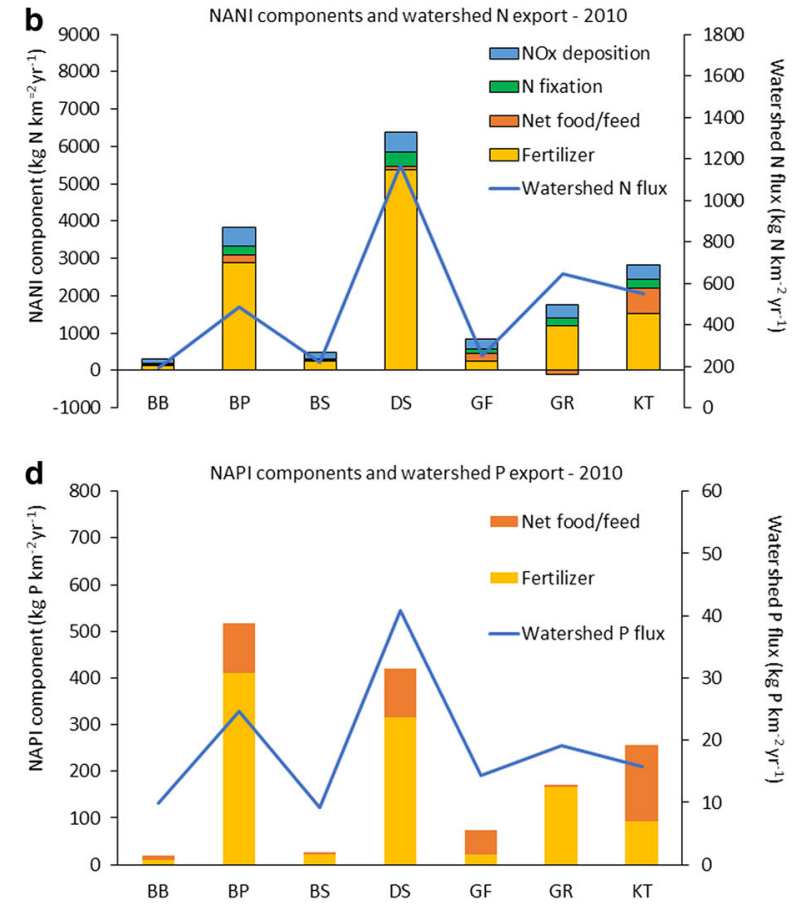

GR and KT, and for the Baltic overall. For forested watersheds, especially in northern regions (BB, BS, and GF), atmospheric deposition represents a more significant component of total $\mathrm{N}$ inputs. Labels refer to basins as in Fig. 4

calculation, as discussed above) can also contribute to the overall uncertainties. Some simplifying assumptions that require fewer data may be considered to be more reasonable as the watershed size increases (Howarth et al. 2012). For example, many NANI studies account for only the oxidized form of $\mathrm{N}$ deposition, assuming that most of the ammonia/ ammonium emission from a watershed is redeposited on the same watershed. Our estimates of the non-local reduced $\mathrm{N}$ contribution of reduced $\mathrm{N}$ deposition range between 37 and $54 \%$ of the oxidized $\mathrm{N}$ deposition (or $4-17 \%$ of NANI) for the seven Baltic catchment regions (Table S10), so were not considered further. Earlier studies that extensively tested the impacts of various alternative accounting methods (e.g., Han and Allan 2008; Hong et al. 2011, 2013) indicated that, although switching a calculation method can cause considerable changes in the NANI values for a subset of watersheds that are highly sensitive to the particular assumption altered, the overall nutrient budget at a large basin scale tends to be robust. In this case, including nonlocal reduced $\mathrm{N}$ deposition, or even all 


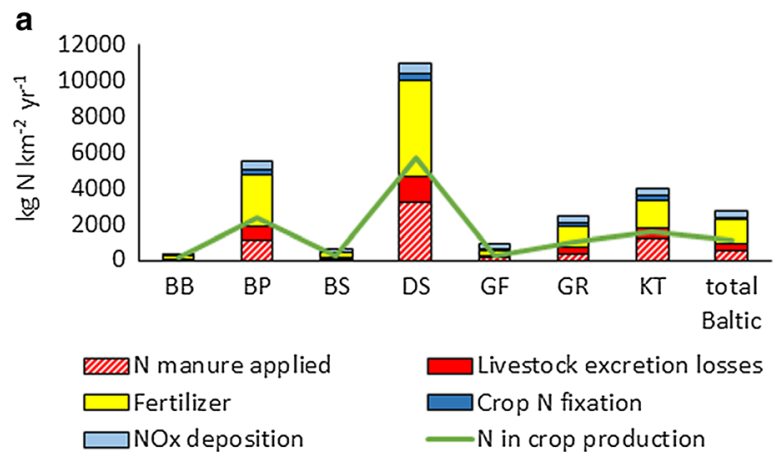

Fig. 6 Crop nitrogen (a) and phosphorus (b) demands for the watersheds of major Baltic basins in 2010 (green lines) and potential nutrient sources that may meet those demands. Manure $\mathrm{N}$ and $\mathrm{P}$ productions (red bar, hashed) represent the proportions of

reduced $\mathrm{N}$ deposition, has negligible impact on the relationships between NANI and riverine $\mathrm{N}$ fluxes at the scale studied (Fig. S2, supplemental materials).

Agricultural nutrient inputs versus crop demand

In a number of basins, the magnitudes of nutrients in livestock excretion (sum of manure applied and excretion losses) are close to that of crop production (Fig. 6). A higher proportion of livestock excretion of $\mathrm{N}$ (Fig. 6a) is estimated to be lost before it can be applied to fields as manure than is true for $\mathrm{P}$ (Fig. 6b) because of additional loss pathways (ammonia volatilization and denitrification losses, etc.). While it is reasonable to assume a fertilizer-replacement value of 1 for $\mathrm{P}$ in manure (e.g., $1 \mathrm{~kg} \mathrm{P}$ in manure $=1 \mathrm{~kg} \mathrm{P}$ in commercial fertilizer; Eghball et al. 2005), the fertilizer-replacement value of $\mathrm{N}$ in manure is generally lower and more variable, depending on a number of factors such as manure type, treatment and carbon content (Eghball et al. 2002) which relate to the above loss pathways. Agricultural systems will never be perfectly efficient because of unavoidable losses. However, reducing $\mathrm{N}$ loss during manure production and application, especially increased ammonia volatilization from surfacedressed manure applications, could increase the potential availability of livestock excretion for its application to croplands, thereby potentially reducing inorganic fertilizer use (Buckwell and Nadeu 2016).

Although $\mathrm{N}$ deposition and agricultural $\mathrm{N}$ fixation provide additional sources of nitrogen to crops, their contribution to the overall $\mathrm{N}$ budget is comparatively small in agricultural regions of the Baltic, irrespective

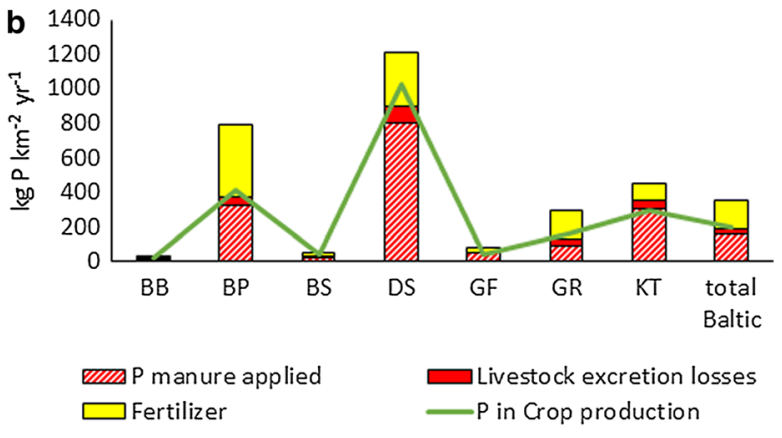

livestock $\mathrm{N}$ and $\mathrm{P}$ excretion, respectively, that are converted to manure. The solid red portions represent the livestock $\mathrm{N}$ and $\mathrm{P}$ excretion lost (via volatilization, leaching, etc.) during manure production. Labels refer to basins as in Fig. 4. (Color figure online)

of the details of the assumptions about oxidized vs reduced $\mathrm{N}$ contributions. However, in the northernmost, sparsely populated Baltic catchments (Bothnian Bay, Bothnian Sea), potential contributions of longdistance atmospheric transport are important, because atmospheric $\mathrm{N}$ deposition is a significant component of NANI (Eriksson Hägg et al. 2012).

Our results suggest that more efficient use of manure could reduce the use of mineral fertilizer, thereby lowering nutrient surpluses. Inefficient use of manure $\mathrm{N}$ and $\mathrm{P}$ can result from mismatches between the locations of intensive livestock production and areas of crop production, and associated losses in transport and handling of manure (Oenema et al. 2007). Bringing livestock and crop production closer together, and applying manure and mineral fertilizer at levels closer to the apparent net crop demand should see improvements in both agricultural efficiency and environmental quality (Nesme et al. 2015; Garnier et al. 2016).

\section{Conclusions}

The NANI/NAPI framework of nutrient accounting is a robust framework for estimating nutrients to major basins of the Baltic Sea, and thus can serve as the basis for regional and interregional comparisons and analyses of meaningful environmental management strategies. Within the Baltic, significant variations in nutrient inputs exist, primarily along a north-south gradient. Direct relationships between NANI/NAPI and corresponding watershed exports of TN/TP to the Baltic have been documented (Hong et al. 2012) and this analysis, using refined data available from 
EuroStat and other sources, continues to support this conclusion. Further, decadal changes in TN and TP fluxes across major subbasins between 2000 and 2010 were directly related to corresponding changes in NANI and NAPI which were strongly affected by changes in fertilizer use and, to some degree, by changes in net food and feed imports. Finally, it appears that, in principle, much of the current nutrient demand by crops and forage lands could be satisfied by livestock excretion, if effectively managed. Switching to a manure-based system would require careful investigation at several management scales to ensure that organic nutrient export to waters does not become an unintended impact on the Baltic Sea ecosystem. This potential management option, combined with the observation of the direct response of TN/TP export to NANI/NAPI change, suggests that significant reductions in nutrient loading could occur by reducing mineral fertilizer application through effective manure production and application throughout the region. Strategies to do so should be developed on an international (EU and neighbors), national, regional and watershed basis, depending upon the locally predominant livestock and crop mix, and corresponding best management practices appropriate for local soils and climatic conditions.

\begin{abstract}
Acknowledgements We dedicate this work to the memory of our esteemed colleague and mentor, Fredrik Wulff, whose insights and humor informed much of this and previous work in the Baltic. We gratefully acknowledge Svetlana Ivanova, Vice President, Eastern Europe and Central Asia Division, International Plant Nutrition Institute, for her assistance in obtaining statistics of fertilizer nutrient consumption in western Russian oblasts. We also thank Alexander Sokolov for his insight and assistance in considering aspects of nitrogen deposition in the region, Bob Howarth for his continuing support, and three anonymous reviewers for their thoughtful comments which improved this manuscript. Funding was provided by Baltic Eye and the Baltic Sea 2020 Foundation.
\end{abstract}

\section{Compliance with ethical standards}

Conflict of interest The authors are aware of no potential conflicts of interest.

Open Access This article is distributed under the terms of the Creative Commons Attribution 4.0 International License (http:// creativecommons.org/licenses/by/4.0/), which permits unrestricted use, distribution, and reproduction in any medium, provided you give appropriate credit to the original author(s) and the source, provide a link to the Creative Commons license, and indicate if changes were made.

\section{References}

American Society of Agricultural Engineers (ASAE) 2005 ASAE standards, manure production and characteristics publication ASAE D384.2, March 2005

Anderson DM, Glibert PM, Burkholder JM (2002) Harmful algal blooms and eutrophication: nutrient sources, composition, and consequences. Estuaries 25(4):704-726

Belstat (2001, 2010-2015). Regions of the Republic of Belarus, statistical yearbook 2001, 2010-2015. http://www.belstat. gov.by/

Belstat (2009-2015). Agriculture of the Republic of Belarus, statistical yearbook, 2009-2015. http://www.belstat.gov. by/

Bennett EM, Carpenter SR, Caraco NF (2001) Human impact on erodable phosphorus and eutrophication: a global perspective. BioScience 51:227-234

Billen G, Silvestre M, Grizzetti B, Leip A, Garnier J, Voss M, Howarth R, Bouraoui F et al (2011) Nitrogen flows fromEuropean regional watersheds to coastalmarine waters. In: Sutton MA, Howard CM, Erisman JW, Billen G, Bleeker A, Grennfelt P et al (eds) The European nitrogen assessment. Cambridge University Press, New York, pp 271-297

Boyer EW, Goodale CL, Jaworski NA, Howarth RW (2002) Anthropogenic nitrogen sources and relationships to riverine nitrogen export in the northeastern U.S.A. Biogeochemistry 57(58):137-169

Buckwell A, Nadeu E (2016) Nutrient recovery and reuse (NRR) in European agriculture. A review of the issues, opportunities, and actions. RISE Foundation, Brussels

Carstensen J, Andersen JH, Gustafsson BG, Conley DJ (2014) Deoxygenation of the Baltic Sea during the last century. Proc Natl Acad Sci USA 111(15):5628-5633

Claesson S, Steineck S (1991) Växtnäring, hushållning och miljö (in Swedish) which can be translated as: "Plant nutrition, economy and environment". Sveriges Lantbruksuniversitet, Uppsala

Dalgaard T, Hansen B, Hasler B, Hertel O, Hutchings NJ, Jacobsen BH, Jensen LS, Kronvang B, Olesen JE, Schjørring JK, Kristensen IS (2014) Policies for agricultural nitrogen management-trends, challenges and prospects for improved efficiency in Denmark. Environ Res Lett 9(11):115002

Diaz RJ, Rosenberg R (2008) Spreading dead zones and consequences for marine ecosystems. Science 321(5891): 926-929

Eghball B, Wienhold BJ, Gilley JE, Eigenberg RA (2002) Mineralization of manure nutrients. J Soil Water Conserv 57(6):470-473

Eghball B, Wienhold BJ, Woodbury BL, Eigenberg RA (2005) Plant availability of phosphorus in swine slurry and cattle feedlot manure. Agron J 97(2):542-548

Eriksson Hägg H, Humborg C, Swaney DP, Mörth C-M (2012) Riverine nitrogen export in Swedish catchments dominated by atmospheric inputs. Biogeochemistry 111:203-217

European Environment Agency (EEA) 2015. National Emissions Ceilings Directive status report 2014. EEA technical report no $7 / 2015$ 
FSSS (2001-2013) Russian Federation Federal State Statistics Service. http://www.gks.ru/bgd/regl/B09_16/IssWWW. exe/Stg/01-07.htm, /01-06n.htm, /01-06o.htm; http:// www.gks.ru/bgd/regl/B14_16/Main.htm

FSSS (2008) Demographic yearbook of Russia. Russian Federation Federal State Statistics Service

Galloway JN, Dentener FJ, Capone DG, Boyer EW, Howarth RW, Seitzinger SP, Asner GP, Cleveland CC, Green PA, Holland EA, Karl DM (2004) Nitrogen cycles: past, present, and future. Biogeochemistry 70(2):153-226

Garnier J, Lassaletta L, Billen G, Romero E, Grizzetti B, Némery J, Thi Phuong Quynh Le, Pistocchi C, AissaGrouz N, Thi Nguyet Minh Luu, Vilmin L, Dorioz JM (2015) Phosphorus budget in the water-agro-food system at nested scales in two contrasted regions of the world (ASEAN-8 and EU-27). Glob Biogeochem Cycles 29:1348-1368

Garnier J, Anglade J, Benoit M, Billen G, Puech T, Ramarson A, Passy P, Silvestre M, Lassaletta L, Trommenschlager JM, Schott C (2016) Reconnecting crop and cattle farming to reduce nitrogen losses to river water of an intensive agricultural catchment (Seine basin, France): past, present and future. Environ Sci Policy 63:76-90

Grizzetti B, Bouraoui F, Aloe A (2007) Spatialised European nutrient balance. JRC scientific and technical reports (EUR collection), JRC36653, ISBN 978-92-79-05057-2, Institute for Environment and Sustainability

Han H, Allan JD (2008) Estimation of nitrogen inputs to catchments: comparison of methods and consequences for riverine export prediction. Biogeochemistry 91:177-199

Han H, Allan JD, Scavia D (2009) Influence of climate and human activities on the relationship between watershed nitrogen input and river export. Environ Sci Technol 43:1916-1922

Han H, Bosch N, Allan JD (2011) Spatial and temporal variation in phosphorus budgets for 24 watersheds in the Lake Erie and Lake Michigan basins. Biogeochemistry 102:45-58

HELCOM (2015) Updated Fifth Baltic Sea pollution load compilation (PLC-5.5). Baltic Sea Environment Proceedings No. 145. http://www.helcom.fi/Lists/Publications/ BSEP145_Lowres.pdf

Hong B, Swaney DP, Howarth RW (2011) A toolbox for calculating net anthropogenic nitrogen inputs (NANI). Environ Model Softw 26:623-633

Hong B, Swaney DP, Mörth C-M, Smedberg E, Eriksson Hägg H, Humborg C, Howarth RW, Bouraoui F (2012) Evaluating regional variation of net anthropogenic nitrogen and phosphorus inputs (NANI/NAPI), major drivers, nutrient retention pattern and management implications in the multinational areas of Baltic Sea basin. Ecol Model 227:117-135. doi:10.1016/j.ecolmodel.2011.12.002

Hong B, Swaney DP, Howarth RW (2013) Estimating net anthropogenic nitrogen inputs (NANI) to US watersheds: comparison of methodologies. Environ Sci Technol 47(10):5199-5207. doi:10.1021/es303437c

Howarth RW (2008) Coastal nitrogen pollution: a review of sources and trends globally and regionally. Harmful Algae 8:14-20

Howarth RW, Billen G, Swaney DP, Townsend A, Jaworski N, Lajtha K, Downing JA, Elmgren R, Caraco N, Jordan T, Berendse F, Freney J, Kudeyarov V, Murdoch P, Zhao- liang Zhu (1996) Riverine inputs of nitrogen to the North Atlantic Ocean: fluxes and human influences. Biogeochemistry 35:75-139

Howarth RW, Swaney DP, Boyer EW, Marino R, Jaworski N, Goodale C (2006) The influence of climate on average nitrogen export from large watersheds in the northeastern United States. Biogeochemistry 79:163-186

Howarth RW, Swaney DP, Billen G, Garnier J, Hong B, Humborg C, Johnes P, Mörth C-M, Marino RM (2012) Nitrogen fluxes from large watersheds to coastal ecosystems controlled by net anthropogenic nitrogen inputs and climate. Front Ecol Environ 10(1):37-43. doi:10.1890/ 100178

Ilnicki P (2014) Emissions of nitrogen and phosphorus into rivers from agricultural land-selected controversial issues [Ładunki azotu i fosforu wprowadzane do rzek z terenów rolniczych-wybrane dyskusyjne problemy]. J Water Land Dev 23(1):31-40

Lander CH, Moffitt D, Alt K (1998) Nutrients available from livestock manure relative to crop growth requirements. Resource assessment and strategic planning working paper 98-1, United States Department of Agriculture, Natural Resources Conservation Service

National Research Council (NRC) (2000) Clean coastal waters: understanding and reducing the effects of nutrient pollution. National Academy of Sciences, Washington, DC

National Statistical Committee of the Republic of Belarus (2013) Agriculture of the Republic of Belarus. Statistical book, Minsk. ISBN 978-985-7015-35-1 (covers years 2005-2012). http://www.belstat.gov.by/

National Statistical Committee of the Republic of Belarus (2015) Agriculture of the Republic of Belarus. Statistical book. Minsk. ISBN 978-985-7115-30-3 (covers years 2010-2014) http://www.belstat.gov.by/

Nesme T, Senthilkumar K, Mollier A, Pellerin S (2015) Effects of crop and livestock segregation on phosphorus resource use: a systematic, regional analysis. Eur J Agron 71:88-95. doi:10.1016/j.eja.2015.08.001

OECD (2007a) OECD and EUROSTAT: gross phosphorus balances handbook. http://www.oecd.org/greengrowth/ sustainable-agriculture/40820243.pdf

OECD (2007b) OECD and EUROSTAT: gross nitrogen balances handbook. http://www.oecd.org/greengrowth/ sustainable-agriculture/40820234.pdf

Oenema O, Oudendag D, Velthof GL (2007) Nutrient losses from manure management in the European Union. Livest Sci 112:261-272

Pastuszak M, Stålnacke P, Pawlikowski K, Witek Z (2012) Response of Polish rivers (Vistula, Oder) to reduced pressure from point sources and agriculture during the transition period (1988-2008). J Mar Syst 94:157-173

Romero E, Gamier J, Billen G, Peters F, Lassaletta L (2016) Water management practices exacerbate nitrogen retention in Mediterranean catchments. Sci Total Environ 573:420-432

Russell MJ, Weller DE, Jordan TE, Sigwart KJ, Sullivan KJ (2008) Net anthropogenic phosphorus inputs: spatial and temporal variability in the Chesapeake Bay region. Biogeochemistry 88:285-304

Russian Federation Federal State Statistical Service (FSSS) (2015) http://www.gks.ru/ 
Rybicki S (1997) Advanced wastewater treatment report no. 1, phosphorus removal from wastewater-a literature review, Joint Polish-Swedish Reports, Division of Water Resources Eng., KTH, TRITA-AMI REPORT 3042, ISSN 1400-1306, ISRN KTH/AMI/REPORT 3042-SE, ISBN 91-7170-247-4

Schaefer SC, Alber MA (2007) Temperature controls a latitudinal gradient in the proportion of watershed nitrogen exported to coastal ecosystems. Biogeochemistry 85:333-346

Sheldrick W, Syers JK, Lingard J (2003) Contribution of livestock excreta to nutrient balances. Nutr Cycl Agroecosyst 66:119-131

Smith VH (2003) Eutrophication of freshwater and coastal marine ecosystems a global problem. Environ Sci Pollut Res 10(2):126-139. doi:10.1065/espr2002.12.142

Statistical Yearbook of Russia (1999-2015) Russian Federation Federal State Statistical Service (FSSS), Moscow
Swaney DP, Hong B, Ti C, Howarth RW, Humborg C (2012a) Net anthropogenic nitrogen inputs to watersheds and riverine $\mathrm{N}$ export to coastal waters: a brief overview. Curr Opin Environ Sustain 4:203-211

Swaney DP, Santoro RL, Howarth RW, Hong B, Donaghy KP (2012b) Historical changes in the food and water supply systems of the New York City Metropolitan Area. Reg Environ Change 12:363-380

Tybirk K, Luostarinen S, Hamelin L, Rodhe L, Haneklaus S, Poulsen HD, Jensen ALS (2013) Sustainable manure management in the Baltic Sea Region. Baltic forum for innovative technologies for sustainable manure management. http://www.balticmanure.eu/

Zhang W, Swaney DP, Hong B, Howarth RW, Han H, Li X (2015) Net anthropogenic phosphorus inputs and riverine phosphorus fluxes in highly populated headwater watersheds in China. Biogeochemistry 126:269-283 